\title{
New insights on the bacterial canker of kiwifruit (Pseudomonas syringae pv. actinidiae)
}

\author{
Irene Donati, Giampaolo Buriani, Antonio Cellini, Sofia Mauri, Guglielmo Costa \\ and Francesco Spinelli* \\ Department of Agricultural Sciences, Alma Mater Studiorum - University of Bologna, Viale Fanin, Bologna, Italy
}

Received 4 April 2014; accepted 16 May 2014

\begin{abstract}
Since 2008, Pseudomonas syringae pv. actinidiae, the causal agent of bacterial canker of kiwifruit has become the main pathogen of yellow and green fleshed kiwifruit. All major kiwifruit producing countries in the world have been affected by this bacterial pathogen, leading to substantial economic losses. This review presents the current knowledge on various aspects about the origin, epidemiology, detection and control strategies of Pseudomonas syringae pv. actinidiae.
\end{abstract}

Keywords: Bacterial diseases, fruit trees, disease diagnosis, control strategies, physiological and molecular plant-pathogen interaction

\section{Introduction}

Pseudomonas syringae pv. actinidiae (Psa), the causal agent of bacterial canker of kiwifruit, has become in less than five years the main threat for yellow and green fleshed kiwifruit production (A. chinensis and A. deliciosa, respectively). Before 2008, Psa had been reported in Japan [1], China [2], Korea [3] and Italy [4], and in all cases, the pathogen was isolated from Actinidia deliciosa cv. Hayward.

The first epidemic outbreaks occurred in 2008 in central Italy (Lazio) [5], and they were followed by a spread to North Italy (i.e. Emilia Romagna and Piemonte, [6, 7]). In 2010, the disease was recorded in France 2010 [8] and Portugal [9], and in 2011, it reached Spain [10] and Turkey [11].

An independent outbreak occurred in New Zealand in 2010 [12] and Chile in 2011 [13]. Currently, the bacterial canker has spread to a pandemic scale [14] and it is the major cause of severe economic losses in all countries, such as Italy and New Zealand, where kiwifruit is a strategic crop [15].

In Italy, between 2010 and 2012, vast areas (>2000 hectares) of kiwifruit vineyards were either cut back or destroyed due to Psa. The economic impact for farmers is estimated to be $€ 20000 /$ hectare/year in production losses, $€ 50000 /$ hectare for orchard investment and $€ 15,000 /$ hectare to destroy plants to stop the spread of infection, reducing production in orchards by 10-50\% [16]. In France, Psa has been found in approx. $10 \%$ of the 4700 hectares of kiwifruit, and in some regions, 50\% of plants have been confirmed to be infected [17].

In New Zealand, Psa symptoms were initially noticed on A. chinensis cv. Hort16A in the Bay of Plenty region during October 2010. Very soon after, the disease also spread to the more resistant species A. deliciosa cv. Hayward $[12,14]$. In less than 3 years after its discovery, in New Zealand, Psa has been identified in more than 1400 orchards, representing the $52 \%$ of the surface cultivated with kiwifruit [18]. The most recent Kiwifruit Vine Health Psa Statistics report (March 2014) [19] stated that 11084 hectares have been confirmed as infected by Psa, representing $81 \%$ of total

${ }^{*}$ Corresponding author: Francesco Spinelli, Department of Agricultural Sciences, Alma Mater Studiorum - University of Bologna, Viale Fanin 46, 40127 Bologna, Italy. Tel.: +39 051 2096436; Fax:+39 051 2096401; E-mail: francesco.spinelli3@ unibo.it. 
surface dedicated to kiwifruit in New Zealand. A recent report by Lincoln University’s Agribusiness and Economics Research Unit has predicted, for New Zealand, economic losses of up to \$410 million over the next 5 years [20].

In parallel with rapid transmission and the increased pathogenicity of strains responsible for the 2008 pandemics, research has intensified and many scientific papers on the bacterial canker of kiwifruit have been published. The increasing concerns about the diseases led also to the build up of collaborative research programs. The Italian Ministry of Agriculture, Food and Forestry allocated a total of 1,5 million euros for the Interact and Ardica projects, focused on elucidating key aspects of Psa biology and epidemiology, host-pathogen interactions, and on the development of reliable and sustainable control strategies, including the breeding of novel resistant varieties. The Regione Emilia Romagna funded three consecutive projects starting from 2008 until 2015, while, in 2014, the European Union funded the DROPSA project (No 613678) "Strategies to develop effective, innovative and practical approaches to protect major European fruit crops from pests and pathogens" (6 million euros) - www.dropsaproject.eu.

\section{The pathogen}

Pseudomonas syringae pv. actinidiae (Proteobacteria, gamma subdivision; Order Pseudomonadales; Family Pseudomonadaceae; Genus Pseudomonas; Pseudomonas syringae species complex, genomospecies 8; pathovar actinidiae) is a Gram negative bacterium, aerobic, motile, and rod-shaped, with polar flagella, oxidase-negative, arginine dihydrolase-negative.

The first Psa genome sequence was published in 2011 [21]. Even though it was a draft, without a fully genome sequence and relative detailed annotation, it provided a first substantial overview of Psa genome features, size (approx. 6 megabases) and complexity. The development of next generation sequencing techniques allowed the obtainment of many Psa genome sequences, which are now fully available [22-24]. Based on comparative genome genetics, a number of effector and virulence genes (e.g. hop and $a v r$ family), either typical of a group of Psa strains or ubiquitous, were highlighted. Moreover, genomic islands, including many genes essential for crucial physiology processes such as pathogenesis (namely, pathogenicity islands) were identified.

At present, more than 1000 P. syringae strains were deep analysed and at least partially annotated and classified in publically available online portals, which allow users to perform sophisticated and computationally efficient analyses of these data [25]. The availability of a such high number of genomes is an extraordinary tool to perform in silico preliminary analysis, which led to more focused and successful applicative researches.

High throughput sequences led to a deep genome analysis based on molecular markers such as SNPs or Multilocus Sequence analysis (MLST) of different genes such as housekeeping, type III effectors and phytotoxin, enabling to draw a phylogenetic tree based on the alignment on many core genome protein sequences, and to understand the phylogenetic connections between different Psa isolates worldwide.

Based on these analyses, it was possible to assess that Psa from the 2008 Italian outbreak, together with the Chilean, the New Zealand and the Chinese strains form a very closely related group that has been described as belonging to a single genetic lineage. These strains are different from the strains isolated earlier in Japan, Korea and Italy in 1992 [26-28].

Strains associated with the first observation in Japan (1984-1989) and in Italy (1992) are almost genetically identical, and all strains of this lineage possess the phaseolotoxin gene cluster located in the chromosome, acquired by horizontal gene transfer $[29,30]$.

The second lineage, isolated in South Korea, differs from the Japanese one for the occurrence of the coronatine gene [31]. It should be noted, however, that the strains from Japan and Korea (first and second group, respectively) have been generally described as less aggressive in comparison to those appeared in Italy in 2008-2011 [1, 33].

In fact, the strains responsible for the current pandemics belong to a third taxonomic group, originally named 'Italian', and subsequently renamed as Psa-V (virulent) in New Zealand [14, 32]. This lineage appears to have replaced the original population in Italy and it is present in France, Spain, Portugal and China. Strains of this group are characterized by the lack of genes for the expression of either phaseolotoxin or coronatine [14, 21]. However, these virulent strains have been reported to possess four putative hop genes that encode for effector proteins, which are part of the type III secretion system in P. syringae species [14]. By the sequencing of peculiar genomic islands of integrative conjugative elements (ICEs), it was possible to determine horizontal genetic transmission of these islands (known to be critical for pathogenesis) from other Pseudomonas syringae pathovars. Moreover, the coordinate study 
of core genome SNPs and the ICEs, combined with disease history, led to hypothesize that the Italian and the New Zealand outbreaks independently originated in China. The Chilean strains also have a Chinese origin [23].

A Psa-LV (Low-Virulence) lineage was also reported, which is widespread within New Zealand and Australia [14, 32]. There is no evidence supporting that strains of this group were responsible for significant economic losses. In addition, the symptomatology in Psa-LV infected plants does not progress beyond leaf spots [14].

In summary, the population of $P$. syringae pv. actinidiae isolated during the recent epidemics of bacterial canker in Europe (Italy 2008-2011, France, Portugal and Spain) shows an excellent correlation between the genetic profile based on rep-PCR (BOX-PCR, ERIC-PCR), MLST, the citrate synthase (cts) haplotypes and biochemical characteristics in various media, suggesting that these epidemics have been caused by strains of the same group [27, 33-35], which was also detected in New Zealand [35]. According to Marcelletti et al. 2011 [28], this population did not evolve from the population that caused the epidemics in 1984-1992 in Japan, but it is rather the product of a recent independent evolution of the pathovar.

\section{Molecular factors relevant to disease development}

The main symptoms of the bacterial canker of kiwifruit are the dark angular necrotic leaf spots, mostly on young leaves [36]. In early spring, a reddish-brown discoloration under the bark, or the production of red-rusty exudate may be observed. Other symptoms are flower necrosis and blight, twig wilting and dieback, reddening of the lenticels, and fruit collapse, due to blockage of vessels in the canes. Typical symptom appearance is shown in Fig. 1.

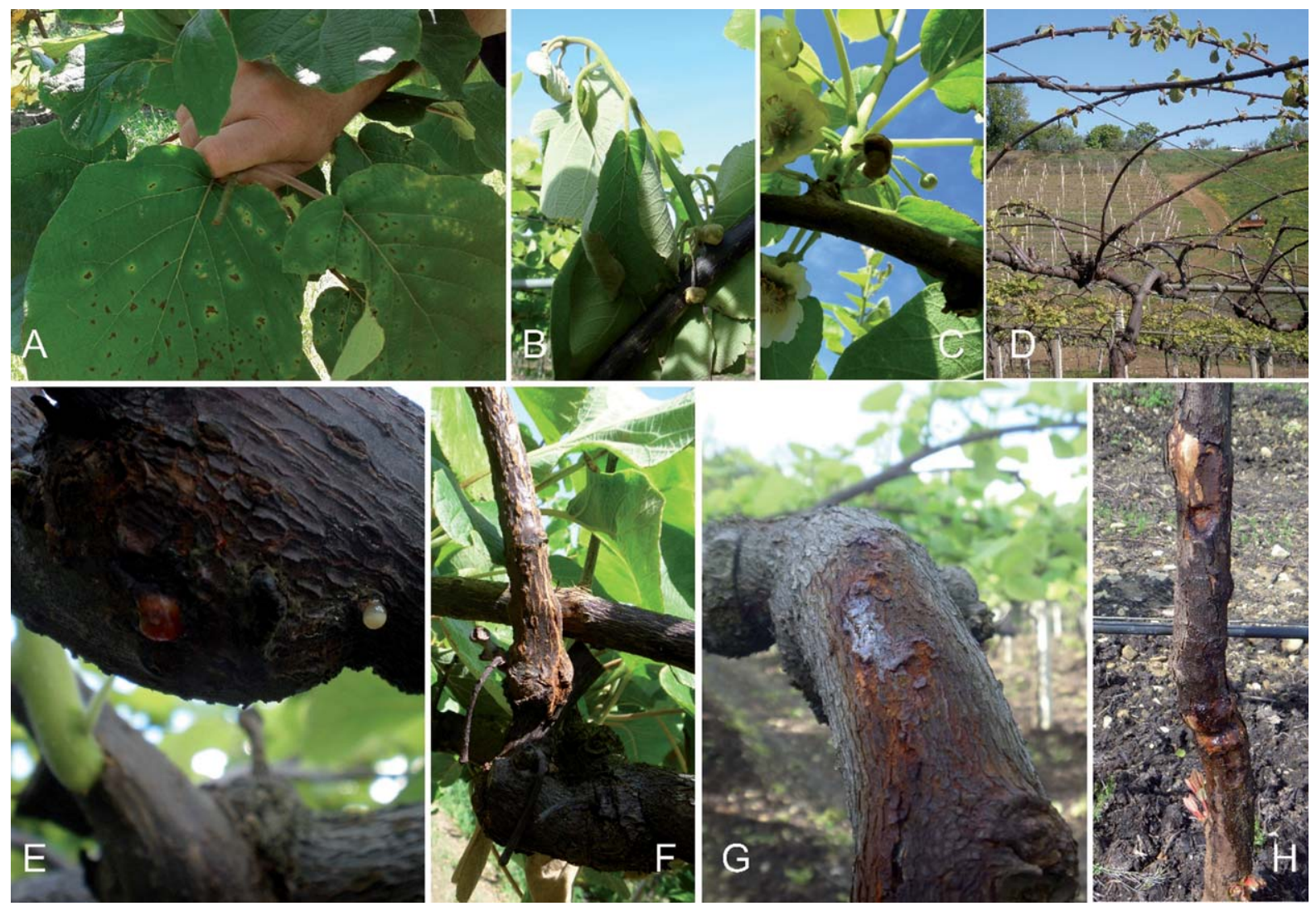

Fig. 1. Symptoms of Pseudomonas syringae pv actinidiae on A. deliciosa cv Hayward A: leaf spots by yellow haloes on A. chinensis plants. B: twig dieback, C: flower necrosis, D: lack of bud break, E: red and white exudates from a cane, F: reddening of the lenticels, G: bacterial canker with exudation, $\mathrm{H}$ : reddish-brown discoloration under the bark below a canker on the trunk and rootstock. 
The host colonization by Psa does not evolve immediately in disease development. It is generally presumed that, during the early colonization stages, the plant is able to maintain the endophytic bacterial population under a threshold by activating basal defence mechanisms. The increased expression of proteins related to oxidative burst and stress (pathogenesis-related proteins, heat shock proteins) was recorded from infected, asymptomatic leaves of A. deliciosa [37].

The trigger of the full bacterial pathogenicity, characterized by symptom development, has not been elucidated yet. Several mechanisms were proposed, including ethylene biosynthesis to silence salicylic acid-mediated plant defences [38] and the inhibition of HSP70-mediated plant responses by the bacterial protein HopI1 [39], suggesting that Psa may synergically attack multiple frontlines of plant defence. While searching for genes responsible for Psa population dynamics, it was demonstrated that Psa does not possess a classic quorum sensing apparatus, but its genome includes three genes belonging to that pathway (called LUX Solos). Such factors may act as receptors, enabling Psa to interact with its host and other organisms, "feeling" signal molecules secreted in the outer space [40], as demonstrated by the reduced growth of LUX-defective Psa mutants in planta. Similar conclusions were drawn after the proteomic analysis of Actinidia apoplast during the asymptomatic [37] and endophytic [39] phases of Psa colonization, which highlighted several bacterial proteins (BamA, OmpA, OmpF) putatively involved in membrane communication.

In addition, the expression of hypersensitivity-related (HRP) and patatin-like proteins (PLP) was affected by Psa infection [39]. While the former were induced by the pathogen, suggesting a role in the formation of necrotic spots, PLPs regulate the execution of cell death and are down-represented in infected shoots.

A metabolomic analysis [41] provided evidence of extracellular polysaccharides production by Psa, which may be related to symptoms such as wilting and oozing. Furthermore, a chlorotic halo is associated with necrotic spots caused by strains expressing phytotoxins, such as phaselotoxin [42] or coronatine [43].

\section{The infection process and disease transmission}

Confocal laser scanning microscopy (CLSM) coupled with the use of bacteria labelled with a fluorescent protein (GFP) allowed to observe, in vivo, the infection process. This approach demonstrated that Psa can infect the plant from stomata, flowers, leaf and fruit abscission scars, broken trichomes and natural wounds [44, 45].

On female flowers, the bacterium was observed on stigmas, ovarium and calyx. In addition, the pathogen can systemically invade the plant after the infection of female flowers. Regarding male flowers, it has been shown that Psa can easily survive on Actinidia spp. pollen grains [46]. Indeed, the infected pollen is a crucial vector of the pathogen [35, 47]. Moreover, the pathogen introduction in New Zealand seems to be related with the import of contaminated pollen from China [23]. A number of studies report the presence of Psa on pollen samples collected from infected and apparently healthy orchards, regardless from the methods used to collect the pollen (e.g. vacuum, manual extraction from flowers, artificial opening of flowers in the lab and anther collection) [47-49].

Few papers examined the possible role of pollinators as vectors of Psa. Psa is able to survive for several days inside the beehive, although the study was conducted in a containment facility, which is an artificial environment rather different from natural orchard conditions [50]. Therefore, a stand-down period of more than nine days is advisable before moving hives from an infected zone into an uninfected area [51]. Honeybees and bumblebees collected from highly infected orchards have been demonstrated to be contaminated by Psa [47]. However, the biological importance of Psa dispersion from flower to flower via pollinators has not yet been fully demonstrated.

Scortichini et al. (2012) [14] noted that bacterial exudates can disperse a large amount of inoculum within and among orchards. The presence of heavily colonised fallen leaves and pruned canes on the orchard floor at the beginning of winter raised questions about the role of the fallen leaves and cane pruning in the life cycle of Psa. Marcelletti et al. 2011 and Tyson et al. 2012, [21, 52] showed that Psa can overwinter in leaf litter and pruning debris. Although many aspects of the epiphytic life of the pathogen have not yet been fully clarified, it has been suggested that Psa may survive and grow epiphytically on asymptomatic flowers and leaves [8, 49].

Epiphytic or endophytic presence of the bacterium in fruits has been excluded by some studies [53], although the bacterium can be detected in experimentally contaminated fruits. In contrast, others authors suggest that the bacterium can be found within the fruits, although at very low populations and only in fruits collected by highly infected orchards [48]. 

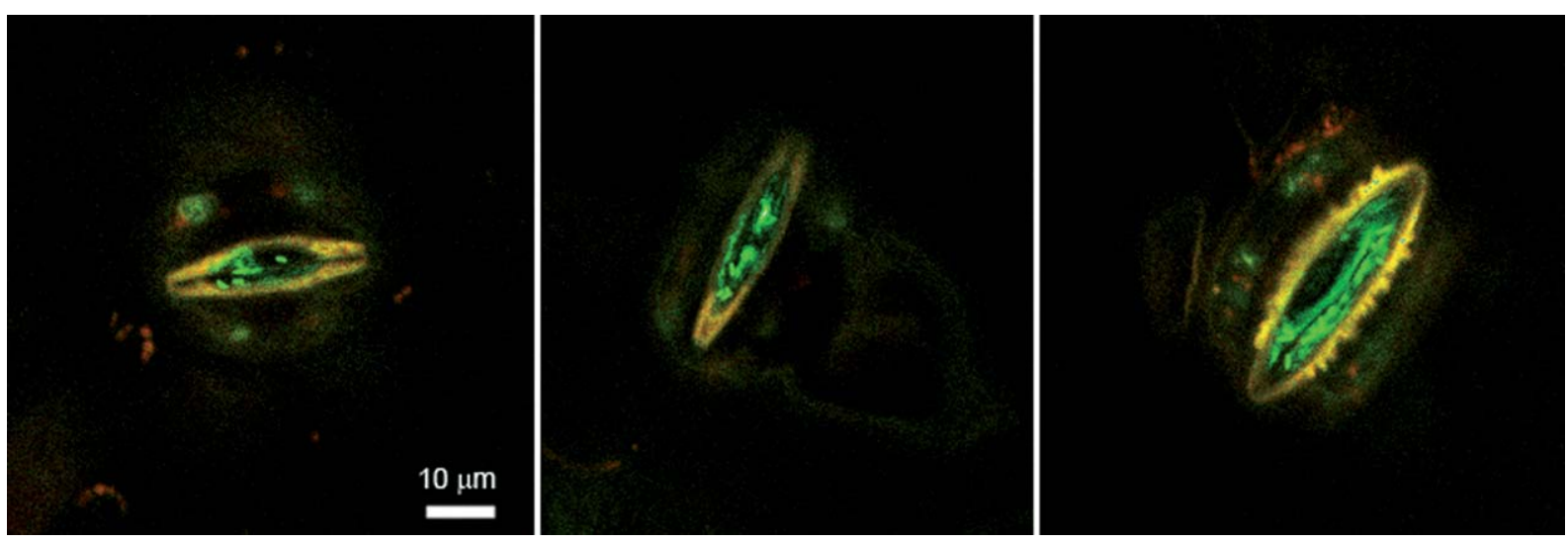

Fig. 2. Deconvoluted CLSM photography showing the localization of GFP-uv labelled Psa on stomata of A. deliciosa (cv Hayward). The bright signal corresponds to GFP-uv fluorescence.

\section{Disease cycle}

A peculiarity of the bacterial canker of kiwifruit is the ease with which the bacterium spreads within and between orchards. Bacterial exudates, which ooze from the cankers during the end of autumn-winter and early spring and are dispersed by the wind, are very effective sources of inoculum [54, 55].

During the spring, the pathogen can move systemically from the leaf to the young stem via the leaf petiole [56]. The systemic displacement of the bacterium within the young twig most probably occurs via the xylem vessels [44], and this represents an uncommon route of plant colonization for a $P$. syringae pathovar.

In the summer, with temperatures increasing above $25^{\circ} \mathrm{C}$, the degree of infection is drastically reduced, even though the bacterium can colonize the host through the stomata and hydathodes [36, 44].

During the autumn, the lenticels and buds are the main colonization sites for the pathogen [57]. In autumn or early winter, the bacterium may survive in a latent form in the cortex tissue of infected branches, and spread throughout the whole plant from late winter to early spring. In late winter/spring, the disease becomes manifest with cankers in trunks and leaders, which may cause the girdling of whole limbs and kill entire vines. Thus, the spread and severity of the disease in late winter to early spring depends primarily on the degree of infection in autumn to early winter.

According to Serizawa et al. (1989) [54], the development of damages associated with Psa occurs in two phases. The first phase takes place in autumn/winter and it consists in damages to the main vine structure and in overwintering canes. The second phase, in spring, involves the new seasons' growth (leaves, flowers and canes). The pathogen infects the host through stomata (Fig. 2), hydathodes, lenticels, trychomes, leaf scars or wounds, and can progress to the roots where it overwinters [7, 44].

The cycle of disease of Psa, proposed in Fig. 3, applies to Italy but is probably different in other growing areas, such as New Zealand, where deep frosts are rare, the rains are more regularly distributed throughout the year and, during the summer, the temperatures are lower than those generally recorded in the Mediterranean climate.

\section{The influence of microclimatic conditions on the disease development}

The microclimate in the orchard is critical in determining the local severity and diffusion of disease. Rainy and humid weather conditions and mild temperature favour the bacterial infection. Thus, the highest risk of bacterial canker is in areas and seasons in which the combination of such conditions is more frequent.

High relative humidity and rain reduces the latent period between infection and symptom development [55]. Furthermore, strong winds and heavy rainfall favour the disease, as recorded for many other bacterial plant diseases, since injuries to the plants and dispersal of the bacterial exudates to the wounds and/or natural openings are likely 


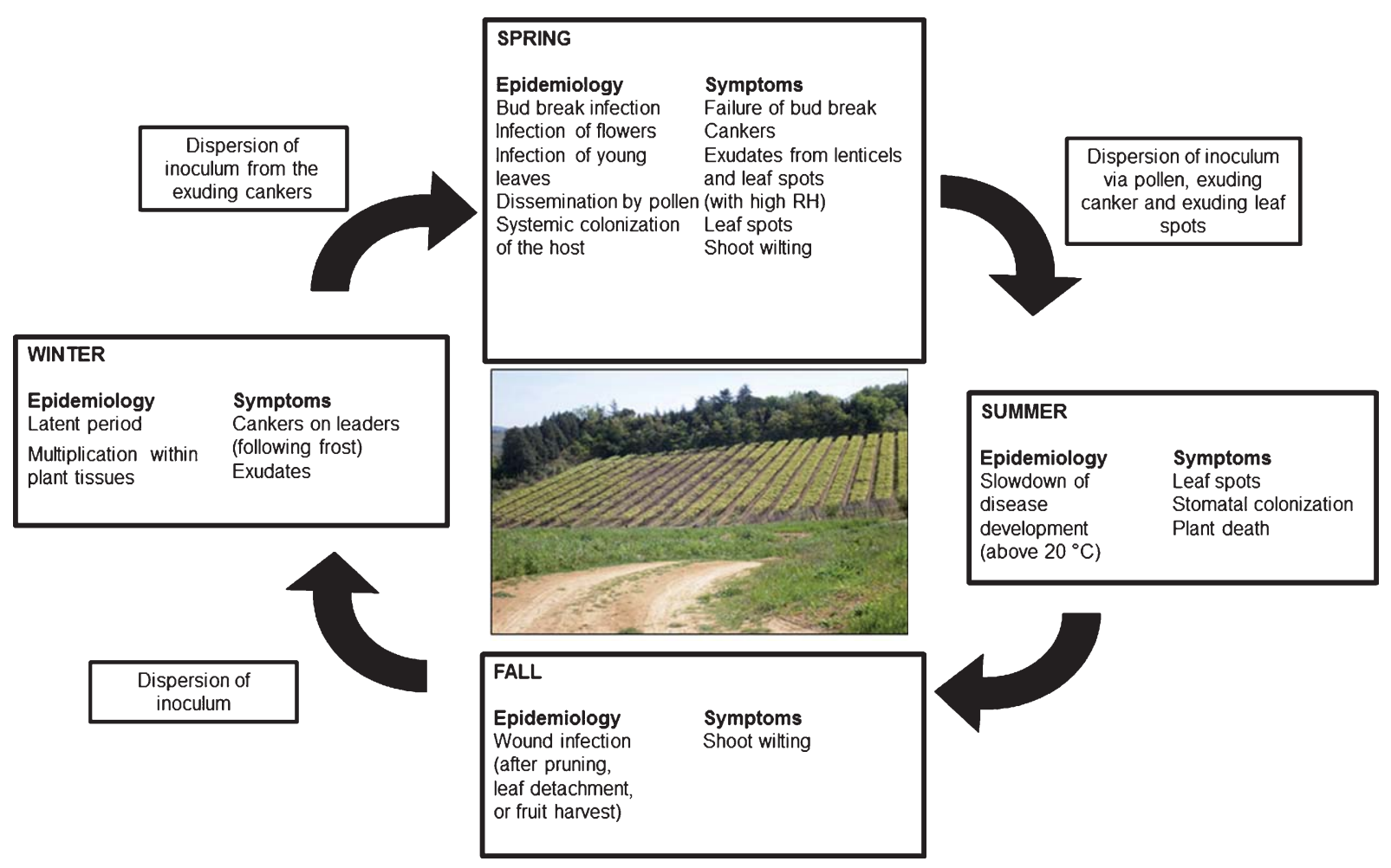

Fig. 3. Cycle of disease of Pseudomonas syringae pv. actinidiae. The disease cycle starts in spring with flowers, bud and leaves infection.

to occur [54]. Once the host plants are infected, the disease development is largely determined by temperature and plant physiological status.

Psa causes disease at relatively low temperatures, since its optimum growth temperature on new canes is $12-18^{\circ} \mathrm{C}$ [58], like $P$. syringae pv. syringae [59]. At temperatures above $20^{\circ} \mathrm{C}$ and below $15^{\circ} \mathrm{C}$, the disease severity is reduced. Above $22^{\circ} \mathrm{C}$, the bacterial growth is abruptly inhibited by the development of wound-healing plant tissue surrounding the infected area, and only a few bacteria survive in diseased tissues during the summer [57]. Therefore, under the Italian conditions, infection of vegetative and fruiting canes occurs mainly in spring. Recurrence of disease on the branches after the winter can be prevented by the formation of wound tissue surrounding the infected parts. When the temperature drops from 22 to $20^{\circ} \mathrm{C}$, the formation of wound tissue gradually decreases, and below $15^{\circ} \mathrm{C}$, the processes of healing are very limited.

In contrast with many Pseudomonas syringae pathovars, Psa does not induce ice nucleation [1], however winter frost and hail favour the occurrence of the disease. A recent study (2014) [15] showed that frost and freeze/thawing promote the migration of the pathogen within Actinidia twigs and between the orchards. Autumn frosts are more dangerous than winter frosts, because they also promote the oozing of exudates from the wounds, which, in some cases, are a secondary source of inoculum.

Damages from Psa are also increased when high populations of $P$. syringae pv. syringae or $P$. viridiflava, two other opportunistic bacterial pathogens attacking Actinidia spp., are present on the plants [7, 60].

\section{Control}

The control of bacterial canker of kiwifruit may only rely on preventive methods, since there is no curative treatment known for Psa. Chemical defences may be preventively applied to help containing the spread of the disease, but they 
are not decisive, and must be accompanied by general measures to reduce inoculum through a good orchard hygiene, and an appropriate field management.

\subsection{Bactericides/bacteriostatic compounds}

Copper-based compounds have played an important role in the control of bacterial diseases on kiwifruit [61]. The efficacy in the reduction of epiphytic bacteria populations on kiwifruit leaves and canes has been shown to vary between the formulations of copper applied and the rate used [62]. Two regimes of copper treatments applied in the field for two seasons in Verona, Italy, provided effective control. The first consisted in two applications of copper sulphate in spring and two in autumn, and the second regime consisted in four applications of copper oxychloride in spring and two in autumn [63]. Additional copper sprays during leaf fall can be an effective way to reduce the risk of infection through leaf scars in the autumn [64].

In Europe, copper-based compounds, such as copper sulphate, are the mainstay of chemical control [65, 66], and are allowed for use by organic growers [67]. In Asian countries and New Zealand the use of streptomycin for control of plant pathogens is allowed [46, 68-70]. Streptomycin has also been used for trunk injection in Korea and appeared to effectively cure infected vines [68].

Unfortunately, both copper compounds and stemptomycin show problems of phytotoxicity, bacterial resistance and residues on fruits. The genes for streptomycin resistance have been reported in Psa [69]. Strains of Psa resistant to copper have already been isolated in Japan [69, 71]. None of the strains isolated since 2008 in Italy showed any resistance or tolerance to copper [26]. The regulatory genes copR and $c o p S$ are required for copper-induced expression of other Cop proteins to provide full copper resistance [72]. Work by Marcelletti et al. (2011) [21] found that copA and copB, but not the two genes $\operatorname{copR}$ and $\operatorname{copS}$ (required for maximal copper resistance), were present in strains belonging to the pandemic lineage.

Other factors, such as persistency, affect copper compounds. A recent study to determine copper rain fastness and longevity on dormant canes, fruit and leaves, showed that canopy density is the main factor determining successful spray coverage, since overly dense canopy zones (e.g. poorly pruned male vines) cannot receive effective spray coverage [73].

A wide range of other protective compounds for the control of the epiphytic populations of Psa has been evaluated by industry and companies in New Zealand [74]. Some product as sterilizers showed some efficacy in glasshouse trials [75]. Two monoterpenes, geraniol and citronellol, have an inhibitory effect against Psa in vitro [26]. Both geraniol and citronellol had previously shown activity against another Gram-negative plant pathogen, Erwinia amylovora, the causal agent of fireblight of pomaceous plant species [76]. The use of terpene compounds such as geraniol in plant disease control and, more specifically, control of Psa, may be limited by phytotoxicity. No data concerning phytotoxicity of these compounds towards Actinidia species are available; however, geraniol has been reported to cause phytotoxicity towards tomato plants [77].

Chitosan, obtained from shrimp shells, showed antimicrobial activity towards a broad spectrum of pathogens, including common plant pathogenic bacteria and fungi. In vitro trials confirmed such effect on Psa [26]. An advantage of chitosan over conventional chemical control methods is its exceptional biocompatibility and biodegradability [78]. In addition, chitosan is a well known stimulator of plant defences [22].

However, while these compounds may reduce epiphytic inoculum loads, albeit temporarily, in most cases they are not effective once the pathogen has entered the plant tissue.

It was recently reported the efficacy of dodecapeptide amides (KYKLFKKILKFL-NH $)_{2}$ ) and two analogs of a hexapeptide amide (WRWYCR-NH 2 ) with antibacterial activity against the Gram negative Psa and Erwinia amylovora [79]. According to in vitro studies, these dodecapeptides are supposed to act by targeting the bacterial membrane leading to its disgregation, but field trials are required to address their efficacy in orchard conditions.

\subsection{Resistance inducers}

Integration of plant-induced resistance into the control program for Psa could provide systemic protection of kiwifruit vines ahead of infection risk events. Based on greenhouse studies, Acibenzolar-S-methyl (ASM) has been shown to be one of the most effective plant elicitors to improve the tolerance of kiwifruit plants to Psa [74]. Work 
carried out in Italy and New Zealand showed that treatment with JA or ethylene did not reduce the incidence of the disease on young kiwifruit seedlings in the glasshouse, but that salicylic acid or derivatives, such as ASM, significantly decreased disease development $[80,81]$. Phytohormone-mediated signalling pathways play a key role in orchestrating the plant response, with cross-talk between salicylic acid (SA), jasmonic acid (JA), and ethylene (ET) pathways tailoring plant defence responses to different pathogens and pests [82, 83]. The SA and JA/ET defence pathways are often mutually antagonistic. Glasshouse studies indicate that kiwifruit resistance to Psa is mediated by the SA signalling pathway, moreover, histological evidence suggests that the pathogen is less able to colonize ASM-treated leaves than untreated leaves [44]. ASM belongs to the benzothiadiazole chemical group and operates as a functional analogue of salicylic acid. It has demonstrated good efficacy against bacterial diseases, including bacterial spot (Xanthomonas axonopodis pv. vesicatoria) and bacterial speck (P. syringae pv. tomato) in tomato [84], fire blight (Erwinia amylovora) in apples [85] and pear [86]. Due to the risk of fruit residues, the foliar application of this compound is restricted.

\subsection{Biological control}

Biological control agents (BCAs) may also contribute to an integrated control of Psa, but knowledge about their efficacy and reliability under a range of environmental conditions is limited. Bacteriophages active against Psa are being isolated and developed for evaluation on kiwifruit [87]. Biological agents with complementary modes of action, such as elicitation of plant responses, competition against Psa or production Psa-specific antimicrobial compounds are sought. Experiments performed in glasshouse conditions suggested that strains of Bacillus subtilis, Pseudomonas fluorescens and Pantoea agglomerans can effectively prevent Psa infection [88]. Other trials provided evidence that the same biological control agents can reduce Psa-V leaf spotting, but only under a low disease pressure [89]. Although such results require further confirmation, the use of BCAs may represent a valuable option for an integrated control strategy.

Recently, a biocontrol strategy based on a cocktail of bacteriophages was introduced [90]. Four promising phages (a siphovirus, a podovirus, a large myovirus, and a virus related to the Myoviridae) were isolated, genetically described and functionally characterized. In particular, this phage cocktail proved to effectively reduce the growth of a number of different Psa strains.

\section{Breeding for resistant varieties}

The recent publication of the first drafted kiwifruit genome sequence [91] has given a great boost to molecular breeding in order to obtain new cultivars with an increased resistance to Psa. In fact, all the Actinidia species cultivated so far are susceptible to the pathogen [8].

Different research institutes started breeding programs based on germplasm screening. The research focused on finding possible resistant parental plants in different Actinidia species such as A. deliciosa, A. chinensis and in the species belonging to the Leiocarpae section, including: A. macrosperma, A. valvata, A. polygama, A. melanandra and A. arguta var. purpurea [92-94]. A different breeding approach, based on induced mutations on Actinidia population and subsequent Psa resistance observation, was also attempted [95].

The breeding for tolerance or resistance is a very important activity for a long lasting strategy to minimise Psa damages. The development of genetic tolerance to bacterial canker in the kiwifruit germplasm (i.e. A. deliciosa and A. chinensis), including the pollinisers, appears as a key factor in a scenario where the pathogen has become endemic in all areas of cultivation [96].

After the screening of 9 new cultivars for tolerance to Psa, 6 of them were found more tolerant to the pathogen than 'Hayward', which was adopted as the reference [65].

The New Zealand breeding programme has recently released 'Gold3', an A. chinensis cultivar with greater tolerance to bacterial canker, as a replacement for 'Hort16A'. This cultivar was originally selected to extend the marketing window for the yellow-fleshed kiwifruit varieties [97]. Advances in the genomic knowledge of the genus Actinidia will be valuable in future development of new cultivars [98]. 
The selection of breeds obtained from resistant and commercially favourable cultivars will require several years, as all of the currently cultivated germplasm is quite susceptible to the disease.

\section{Detection and diagnosis}

The development of rapid and reliable diagnostic methods to screen the propagative material of kiwifruit circulating worldwide is a fundamental step to reduce the further risk of spread of the pathogen to Psa-free regions.

Traditionally, Psa detection has been based on the isolation of bacteria in pure culture followed by identification using rep-PCR [99] or sequencing of 16S rDNA [5].

A PCR identification of bacterial cultures was reported by Koh and Nou (2002) [100] and by Rees-George et al. (2010) [101]. Both procedures appear to be satisfactory for a preliminary investigation, although sometimes aspecific bands and the amplification from P. s. pv. theae can be obtained with both techniques [102]. Recently, other PCRbased techniques were developed in order to overcome these limitations, such as duplex-PCR method [102] and a nested PCR/RFLP assay [103]. A quantitative method, based on real time PCR, was also set up [104], which allows to quantify the Psa population inside symptomless plant organs. The current diagnostic methods are reported in Table 1.

\section{Influence of orchard management on the disease development}

In a modern, holistic view on fruit quality, not only the nutraceutical value of fruits, but also fruit safety and hygienic aspects are crucial. In addition, fruit quality must be associated to economical convenience and environmental sustainability. To achieve these aims, a key step is the adoption of efficient agricultural practices, ensuring a high vineyard productivity, a high quality of fruits, a reduced risk of disease development, a promotion of biodiversity and a minimal impact on the environment. Indeed, the cultural management is an indispensable component of an efficient disease control strategies. Therefore, the role of pollination and the most important cultural management techniques, such as irrigation, fertilization, use of bio-regulators and pruning on the incidence and epidemiology of Psa were examined [105]. All of these cultural management practices, affecting the vine vegetative and reproductive performances, are exploited to force productivity, at the expense of other physiological processes. Therefore, the resulting imbalance can adversely affect the plant's ability to react to abiotic or biotic stress, making it even more susceptible to disease. The time of pruning and nitrogen nutrition (dose and form) are the most critical points in field management, influencing the infection process and promoting the spread of disease from infected to healthy plants [105]. Late pruning (i.e. during weeping time) and pruning during humid periods should be avoided. In addition, pruning cuts should be protected with persistent copper formulates. Regarding fertilization, higher $\mathrm{N}$ rates seem to increase plant susceptibility probably by increasing the sprout of young and succulent shoots [105].

\section{Conclusions}

In the last years, enormous efforts were made to gain information on the interactions between Psa and the kiwifruit species in order to develop a reliable, sustainable and long lasting control strategy of this pandemic disease.

Several aspects related to the pathogen and the disease, such as detection and genomics, identification and characterisation of Psa pathovars, have been examined. A deeper understanding of the pathogen, host, environment and management interactions associated with Psa was obtained, aiming to the development of an effective strategy to eliminate or, at least, reduce the risks of Psa outbreaks worldwide.

Since the climatic conditions play a fundamental role in the progression and spread of the disease, and considering the different climatic conditions occurring in the different areas of kiwifruit production, a single, general strategy is not sufficient for the control of this pathogen. For these reasons, studies should keep investigating all the aspects of this disease for the development of strategies on the different kiwifruit species and growing areas.

An effective prediction model might help to improve the disease control strategies. A real climatic assessment for the determination of suitable areas seems necessary to continue the production of this valuable crop. 


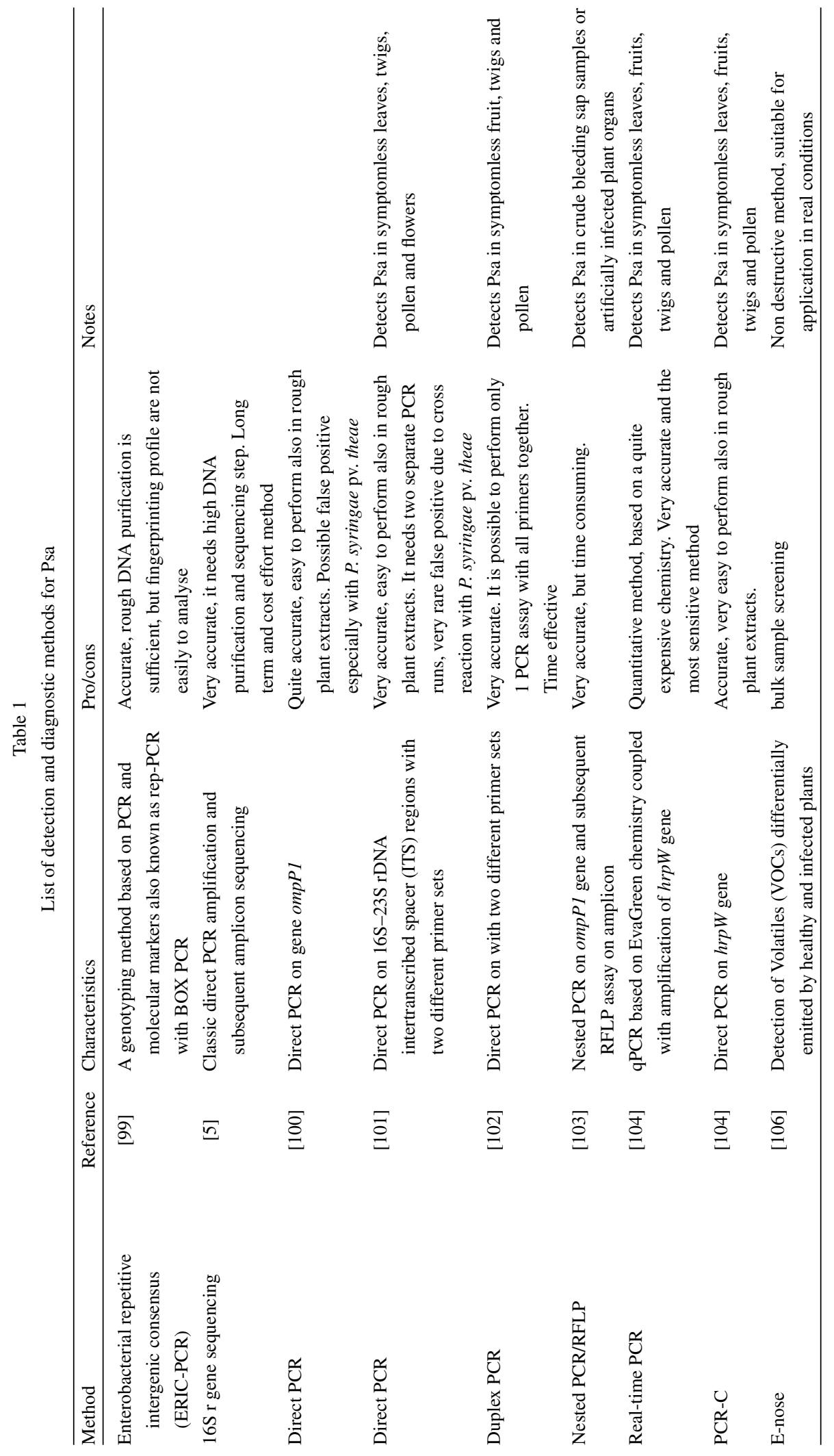


Well-managed orchards, scheduled spray treatments, coupled with improved agronomical and preventive techniques, should be applied in all areas of cultivation to effectively reduce the spread of the pathogen.

Finally, a major effort started aimed to the breeding new cultivars, rootstocks and pollinisers tolerant to Psa. However, the achievement of this goal will require several years. The long time lapse can be substantially reduced if collaborative breeding program will be internationally organised.

In order to deliver effective support tools for the kiwifruit industry, the research should be structured around 3 time steps:

- Short term: identification and delivery of new chemical and biological control options for Psa.

- Medium term: development of new orchard management strategies, to deliver tools, growing methods and production systems that are resistant and resilient to Psa (cultivation under plastic tunnel, decision support system, forecasting model).

- Long term: breeding of new fruiting cultivars, rootstocks and pollinisers that are tolerant to Psa.

\section{References}

[1] Takikawa Y, Serizawa S, Ichikawa T, Tsuyumu S, Goto M. Pseudomonas syringae pv. actinidiae pv. nov.: The causal bacterium of canker of kiwifruit in Japan. Annals of the Phytopathological Society of Japan. 1989;55:437.

[2] Wang Z, Tang X, Liu S. Identification of the pathogenic bacterium for bacterial canker on Actinidia in Sichuan. Journal of Southwest Agricultural University, 1992.

[3] Koh YJ, Cha BJ, Chung HJ, Lee DH. Outbreak and spread of bacterial canker in kiwifruit. Korean Journal of Plant Pathology. 1994;10:68.

[4] Scortichini M. Occurrence of Pseudomonas syringae pv. actinidiae on kiwifruit in Italy. Plant Pathol. 1994;43:1035.

[5] Balestra GM, Mazzaglia A, Quattrucci A, Renzi M, Rossetti A. Current status of bacterial canker spread on kiwifruit in Italy. Australasian Plant Disease Notes. 2009;4:34.

[6] EPPO 2009 - Reporting Service 201111:2009/215.

[7] Mazzaglia A, Renzi M, Taratufolo MC, Gallipoli L, Bernardino R, Ricci L, Quattrucci A, Rossetti A, Balestra MG Cancro batterico dell'actinidia: Il punto della situazione in Italia. Frutticoltura. 2010;9:66.

[8] Vanneste JL, Poliakoff F, Audusseau C, Cornish DA, Paillard S, Rivoal C, Yu J. First report of Pseudomonas syringae pv. actinidiae, the causal agent of bacterial canker of kiwifruit in France. Plant Dis. 2011;95:1311.

[9] Balestra GM, Renzi M, Mazzaglia A. First report of bacterial canker of Actinidia deliciosa caused by Pseudomonas syringae pv. actinidiae in Portugal. New Disease Reports. 2010;22:10.

[10] Abelleira A, López MM, Peñalver J, Aguín O, Mansilla JP, Picoaga A, García MJ. First report of bacterial canker of kiwifruit caused by Pseudomonas syringae pv. actinidiae in Spain. Plant Dis. 2011;95:1583.

[11] Bastas KK, Karakaya A. First report of bacterial canker of kiwifruit caused by Pseudomonas syringae pv. actinidiae in Turkey. Plant Disease. 2011;96:452.

[12] Everett KR, Taylor RK, Romberg MK, ReesGeorge J, Fullerton RA, Vanneste JL, Manning MA. First report of Pseudomonas syringae pv. actinidiae causing kiwifruit bacterial canker in New Zealand. Australasian Plant Disease Notes. 20116:67.

[13] EPPO 2011. First report of Pseudomonas syringae pv. actinidiae in Chile. EPPO Reporting Service. 3:2011/2055.

[14] Scortichini M, Marcelletti S, Ferrante P, Petriccione M, Firrao G. Pseudomonas syringae pv. actinidiae: A re-emerging, multi-faceted, pandemic pathogen. Mol Plant Pathol. 2012;13:631.

[15] Ferrante P, Scortichini M. Frost promotes the pathogenicity of Pseudomonas syringae pv. actinidiae in Actinidia chinensis and A. deliciosa plants. Plant Pathol. 2014;63:12.

[16] Cacioppo O. Aggiornamento dell'actinidicoltura mondiale. Kiwi Informa. 2012;10:12.

[17] Frisch J, Bourgouin B, Picard C. Le PSA, grave bactériose, est sur kiwi en France. Phytoma-La Défense Des Végétaux. 2012;650:22.

[18] Kiwifruit Vine Health. Psa statistics - update 9 May 2012. http://www.kvh.org.nz/vdb/document/453

[19] Kiwifruit Vine Health. Psa Statistics - update 27 March 2014. http://www.kvh.org.nz/vdb/document/453

[20] Greer G, Saunders C. The Costs of Psa-V to the New Zealand Kiwifruit Industry and the Wider Community. In: Report to Kiwifruit Vine Health. Lincoln, New Zealand: Agribusiness and Economics Research Unit, 2012.

[21] Marcelletti S, Ferrante P, Petriccione M, Firrao G, Scortichini M. Pseudomonas syringae pv. actinidiae draft genomes comparison reveal strain-specific features involved in adaptation and virulence to Actinidia species. PLoS ONE. 2011;6:e27297.

[22] Mazzaglia A, Studholme JD, Taratufolo MC, Cai R, Almeida NF, Goodman T, Guttman DS, Vinatzer BA, Balestra GM. Pseudomonas syringae pv. actinidiae (PSA) isolates from recent bacterial canker of kiwifruit outbreaks belong to the same genetic lineage. PloS ONE. 2012; 7:e36518. 
[23] Butler MI, Stockwell PA, Black MA, Day RC, Lamont IL, Poulter RTM. Pseudomonas syringae pv. actinidiae from recent outbreaks of kiwifruit bacterial canker belong to different clones that originated in China. PLoS ONE. 2013;8:e57464.

[24] McCann H, Rikkerink HAE, Bertels F, Fiers M, Lu A, Rees-George J, et al. Genomic analysis of the kiwifruit pathogen Pseudomonas syringae pv. actinidiae provides insight into the origins of an emergent plant disease. PLOS Pathogens. 2013;9(7):e1003503.

[25] Guttman DS. Recent advances in the comparative genomics of Pseudomonas syringae. Proceedings of 1st International Symposium on Bacterial Canker of Kiwifruit (Psa). Mt Maunganui, New Zealand, 2013.

[26] Ferrante P, Scortichini M. Molecular and phenotypic features of Pseudomonas syringae pv. actinidiae isolated during recent epidemics of bacterial canker on yellow kiwifruit (Actinidia chinensis) in central Italy. Plant Pathol. 2010;59:954.

[27] Mazzaglia A, Renzi M, Balestra GM. Comparison and utilization of different PCR-based approaches for molecular typing of Pseudomonas syringae pv. actinidiae strains from Italy. Can J Plant Pathol. 2011;33:8.

[28] Vanneste JL, Yu J, Cornish DA, Tanner DJ, Windner R, Chapman JR, Taylor RK, Mackay J, Dowlut S. Identification, virulence and distribution of two biovars of Pseudomonas syringae pv. actinidiae in New Zealand. Plant Dis. 2013;97:708.

[29] Sawada H, Takeuchi T, Matsuda I. Comparative analysis of Pseudomonas syringae pv. actinidiae and pv. phaseolicola based on phaseolotoxin-resistant ornithine carbamoyltransferase gene $(\operatorname{argK})$ and 16S-23S rRNA intergenic spacer sequences. Appl Environ Microb. 1997;63:282.

[30] Sawada H, Suzuki F, Matsuda I, Saitou N. Phylogenetic analysis of Pseudomonas syringae pathovars suggests the horizontal gene transfer of $\operatorname{argK}$ and the evolutionary stability of $h r p$ gene cluster. J Mol Evol. 1999;49:627.

[31] Shim HH, Koh YJ, Jae-Seoun J, Jung JS. Identification and characterization of coronatine-producing Pseudomonas syringae pv. actinidiae J Microbiol Biotechn. 2003;13:110.

[32] Chapman JR, Taylor RK, Weir BS, Romberg MK, Vanneste JL, et al. Phylogenetic relationships among global populations of Pseudomonas syringae pv. actinidiae. Phytopathology. 2012;102:1034.

[33] Koh YJ, Kim GH, Jung JS, Lee YS, Hur JS. Outbreak of bacterial canker on Hort16A (Actinidia chinensis Planchon) caused by Pseudomonas syringae pv. actinidiae in Korea. N Z J Crop Hort Sci. 2010;38:275.

[34] Vanneste JL, Yu J, Cornish DA, Max S, Clark G. Presence of Pseudomonas syringae pv. actinidiae, the causal agent of bacterial canker of kiwifruit, on symptomatic and asymptomatic tissues of kiwifruit. New Zealand Plant Protection. 2011;64:241.

[35] Chapman J, Taylor R, Alexander B. Second report on characterization of Pseudomonas syringae pv. actinidiae (Psa) isolates in New Zealand. Ministry of Agriculture and Forestry Report. 2011.

[36] Serizawa S, Ichikawa T. Epidemiology of bacterial canker of kiwifruit: 3. The seasonal changes of bacterial population in lesions and of its exudation from lesion. Annals of the Phytopathological Society of Japan. 1993;59:469.

[37] Petriccione M, Salzano AM, Di Cecco I, Scaloni A, Scortichini M. Proteomic analysis of the Actinidia deliciosa leaf apoplast during biotrophic colonization by Pseudomonas syringae pv. actinidiae. J Proteomics. 2014;101:43.

[38] Cellini A, Fiorentini L, Dharmaraj K, Vanneste JL, Cristescu SM, Harren FJM, Costa G, Spinelli F. Evidences of ethylene as a virulence factor for Pseudomonas syringae pv. actinidiae and field measures to limit the kiwifruit plant bacterial canker. Proceedings of the IXth international conference on the plant hormone ethylene. Rotorua, New Zealand, 19-23 March 2012.

[39] Petriccione M, Di Cecco I, Arena S, Scaloni A, Scortichini M. Proteomic changes in Actinidia chinensis shoot during systemic infection with a pandemic Pseudomonas syringae pv. actinidiae strain. J Proteomics. 2013;78:461.

[40] Patel HK, Ferrante P, Covaceuszach S, Lamba D, Scortichini M, Venturi V. The kiwifruit emerging pathogen Pseudomonas syringae pv. actinidiae does not produce AHLs but possesses three luxR solos. PLoS One. 2014;9:e87862.

[41] Andolfi A, Ferrante P, Petriccione M, Cimmino A, Evidente A, Scortichini M. Production of phytotoxic metabolites by Pseudomonas syringae pv. actinidiae, the causal agent of bacterial canker of kiwifruit. J Plant Pathol. 2014;96:169.

[42] Tamura K, Imamura M, Yoneyama K, et al. Role of phaseolotoxin production by Pseudomonas syringae pv. actinidiae in the formation of halo lesions of kiwifruit canker disease. Physiol Mol Plant Pathol. 2002;60:207.

[43] Han HS. Identification and characterization of coronatine producing Pseudomonas syringae pv. actinidiae. J Microbiol Biotechn. 2003;13:110.

[44] Spinelli F, Donati I, Vanneste JL, Costa M, Costa G. Real time monitoring of the interactions between Pseudomonas syringae pv. actinidiae and Actinidia species. Acta Horticulturae. 2011;913:461.

[45] Spinelli F, Donati I, Cellini A, Buriani G, Vanneste J, Yu J, Cornish D, Fiorentini L, Occhi L, Felman C, Mauri S, Kay C, Giacomuzzi V, Costa G. Pseudomonas syringae pv. actinidiae colonization of kiwifruit flowers and methods to prevent infection. Proceedings of 1 st International Symposium on Bacterial Canker of Kiwifruit (Psa). Mt Maunganui, New Zealand, 2013.

[46] Vanneste JL, Giovanardi D, Yu J, Cornish DA, Kay C, Spinelli F, Stefani E. Detection of Pseudomonas syringae pv. actinidiae in kiwifruit pollen samples. New Zealand Plant Protection. 2011;64:246.

[47] Spinelli F, Donati I, Cellini A, Buriani G, Fiorentini L, Rocchi L, Giacomuzzi V, Mauri S, Tosi L, Tacconi G, Vanneste J, Costa G. Pollen-mediated dispersion of Pseudomonas syringae pv. actinidiae. Proceedings of 1st International Symposium on Bacterial Canker of Kiwifruit (Psa). Mt Maunganui New Zealand, 2013.

[48] Gallelli A, Talocci S, L'Aurora A, Loreti S. Detection of Pseudomonas syringae pv. actinidiae, causal agent of bacterial canker of kiwifruit, from symptomless fruits and twigs, and from pollen. Phytopathol Mediterr. 2011;50:462. 
[49] Stefani E, Giovanardi D. Dissemination of Pseudomonas syringae pv. actinidiae through pollen and its epiphytic life on leaves and fruits. Phytopathol Mediterr. 2011;50:489.

[50] Pattemore DE, Hoyte SM, McBrydie HM, Goodwin RM, Moffat B, Yu J, Parry F, Ah Chee A. Survival of Pseudomonas syringae pv. actinidiae and P. s. pv. syringae bacteria on honeybees and in beehives. SPTS. 2011;6109.

[51] Pattemore D, Goodwin M, Vanneste J, McBrydie H, Yorston W, Yu J, Felman C. The presence and survival of Pseudomonas syringae pv. actinidiae on honey bees (Apis mellifera) that have been in infected kiwifruit (Actinidia sp) orchards. SPTS. $2013 ; 8554$.

[52] Tyson JL, Rees-George J, Curtis CL, Manning MA, Fullerton RA. Survival of Pseudomonas syringae pv. actinidiae on the orchard floor over winter. New Zealand Plant Protection. 2012;65:25.

[53] Minardi P, Lucchese C, Ardizzi S, Mazzucchi U. Evidence against the presence of Pseudomonas syringae pv. actinidiae in fruits of Actinidia orchards affected by bacterial canker. J Plant Pathol. 2011;93:43.

[54] Serizawa S, Ichikawa T, Takikawa Y, Tsuyumu S, Goto M. Occurrence of bacterial canker of kiwifruit in Japan: Description of symptoms, isolation of the pathogen and screening of bactericides. Annals of the Phytopathological Society of Japan. 1989;55:427.

[55] Serizawa S, Ichikawa T. Epidemiology of bacterial canker of kiwifruit 4. Optimum temperature for disease development of new canes. Annals of the Phytopathological Society of Japan. 1993;59:694.

[56] Serizawa S, Ichikawa T. Epidemiology of bacterial canker of kiwifruit: 1. Infection and bacterial movement in tissue of new canes. Annals of the Phytopathological Society of Japan. 1993;59:452.

[57] Serizawa S, Ichikawa T, Suzuki H. Epidemiology of bacterial canker of kiwifruit: 5. Effect of infection in fall to early winter on the disease development in branches and trunk after winter. Annals of the Phytopathological Society of Japan. 1994;60:237.

[58] Serizawa S, Ichikawa T. Epidemiology of bacterial canker of kiwifruit: 2 . The most suitable times and environments for infection on new canes. Annals of the Phytopathological Society of Japan. 1993;59:460.

[59] Young JM. Pathogenicity and identification of the lilac pathogen, Pseudomonas syringae pv. syringae van Hall 1902. Annals of Applied Biology. 1991;118:283.

[60] Rossetti A, Fratarcangeli L, Mazzaglia A, Quattrucci A, Renzi M, Ricci L, Gallipoli L, Balestra GM. Characteristic and epidemiology of phytobacteria on Actinidia spp. plants (Caratteristiche e diffusione dei batteri fitopatogeni su Actinidia spp). Italus Hortus. 2009;16:32.

[61] Balestra GM, Varvaro L. Pseudomonas syringae pv. syringae Causal Agent of Disease on Floral Buds of Actinidia deliciosa (A. Chev) Liang et Ferguson in Italy. J Phytopathol. 1997;145:375.

[62] Balestra GM, Bovo M. Effectiveness of copper compounds in the control of bacterial diseases on kiwifruit plants. No 9-03. Acta Hort. 2003;610:399.

[63] Balestra GM. Use of copper formulations to limit bacterial diseases in kiwifruit. (Speciale Actinidia). Rivista di Frutticoltura e di Ortofloricoltura. 2004;66:35.

[64] Young J. Pseudomonas syringae pv. actinidiae in New Zealand. J Plant Pathol. 2012;4:5.

[65] Li M, Tan G, Li Y, Cheng H, Han X, Xue L, Li L. Resistance of different Chinese gooseberry cultivars to Chinese gooseberry bacterial canker caused by Pseudomonas syringae pv. actinidiae and their cluster analysis. Plant Protection. 2004;30:51.

[66] Vanneste JL, Kay C, Onorato R et al. Recent advances in the characterisation and control of Pseudomonas syringae pv. actinidiae, the causal agent of bacterial canker on kiwifruit. Acta Horticulturae. 2011;913:443.

[67] Vanneste JL, Voyle MD. Genetic basis of copper resistance in New Zealand strains of Pseudomonas syringae. New Zealand Plant Protection. 2003;56:109.

[68] Koh YJ, Park S, Lee D. Characteristics of bacterial canker of kiwifruit occurring in Korea and its control by trunk injection. Korean Journal of Plant Pathology. 1996;12:324.

[69] Nakajima M, Goto M, Hibi T. Similarity between copper resistance genes from Pseudomonas syringae pv. actinidiae and P. syringae pv. tomato. J Gen Plant Pathol. 2002;68:68.

[70] Lee JH, Kim JH, Kim GH, Jung JS, Hur JS, Koh YJ. Comparative analysis of Korean and Japanese strains of Pseudomonas syringae pv. actinidiae causing bacterial canker of kiwifruit. Plant Pathology J. 2005;21:119.

[71] Goto M, Hikota T, Nakajima M, Takikawa Y, Tsuyumu S. Occurence and proprieties of copper-resistance in plant pathogenic bacteria. Ann Phytopathol Soc Japan. 2004;60:147.

[72] Cooksey DA. Molecular mechanisms of copper resistance and accumulation in bacteria. FEMS Microbiol Rev. 1994;14:381.

[73] Gaskin RE, Manktelow DW, Cook S, May WA, van Leeuwen RM. Effects of canopy density on spray deposition in kiwifruit. New Zealand Plant Protection. 2013;66:194.

[74] Reglinski T, Vanneste J, Wurms K, Gould E, Spinelli F, Rikkerink E. Using fundamental knowledge of induced resistance to develop control strategies for bacterial canker of kiwifruit caused by Pseudomonas syringae pv. actinidiae. Frontiers in Plant Science. 2013;4:1.

[75] Vanneste JL. Recent progress on detecting, understanding and controlling Pseudomonas syringae pv. actinidiae: A short review. New Zealand Plant Protection. 2013;66:170.

[76] Scortichini M, Rossi P. In vitro susceptibility of Erwinia amylovora (Burril) Winslow et al. to geraniol and citronellol. J Appl Microbiol. 1991;71:113.

[77] Chitwood DJ. Phytochemical based strategies for nematode control. Annu Rev Phytopathol. 2002;40:221. 
[78] Badawy MEI, Rabea EI. A biopolymer chitosan and its derivatives as promising antimicrobial agents against plant pathogens and their applications in crop protection. Int J Carbohydrate Chem. 2011. doi:10.1155/2011/460381

[79] Cameron A, Zoysa GH, Sarojini V. Antimicrobial peptides against Pseudomonas syringae pv. actinidiae and Erwinia amylovora: Chemical synthesis, secondary structure, efficacy, and mechanistic investigations. Biopolymers. 2013;102:88.

[80] Vanneste JL, Spinelli F, Fiorentini L, Yu J, Cellini A, Cornish DA, Donati I, Costa G, Moffat B, Felman C. Reducing susceptibility of kiwifruit plant to Pseudomonas syringae pv. actinidiae by manipulating the plant metabolism using elicitors and hormones. A Snapshot of Psa (Pseudomonas syringae pv. actinidiae). New Zealand Plant Protection Society Symposium, Nelson, New Zealand, 2012.

[81] Spinelli F, Donati I, Cellini A, Buriani G, Mauri S, Rocchi L, Giacomuzzi V, Ortugno C, Costa G, Vanneste J. Optimization of the use of AMS to control bacterial canker of kiwifruit (Pseudomonas syringae pv. actinidiae). Proceedings of 1st International Symposium on Bacterial Canker of Kiwifruit (Psa). Mt Maunganui, New Zealand, 2013.

[82] Robert-Seilaniantz A, Grant M, Jones JD. Hormone crosstalk in plant disease and defense: More than just jasmonate-salicylate antagonism. Annu Rev Phytopathol. 2011;49:317.

[83] Pieterse CM, Van Der Does D, Zamioudis C, Leon-Reyes A, Van Wees SC. Hormonal modulation of plant immunity. Annu Rev Cell Dev Biol. 2012;28:489.

[84] Louws FJ, Wilson M, Campbell HL, Cuppels DA, Jones JB, Shoemaker PB, et al. Field control of bacterial spot and bacterial speck of tomato using a plant activator. Plant Dis. 2001;85:481.

[85] Bastas KK, Maden S. Evaluation of host resistance inducers and conventional products for fire blight management in loquat and quince. Phytoprotection. 2007;88:93.

[86] Spinelli F, Andreotti C, Sabatini E, Costa G, Spada G, Ponti I, et al. Chemical control of fire blight in pear: Application of prohexadionecalcium, Acibenzolar-S-Methyl, and copper preparations in vitro and under field conditions. Proceedings of the Xth International Workshop on Fire Blight, Bologna, Italy, 2006.

[87] Frampton R, Pitman A, Fineran P. Advances in bacteriophage-mediated control of plant pathogens. Int J Microbiol. 2012;1:326452.

[88] Stewart A, Hill R, Stark C. Desktop evaluation on commercially available microbial-based products for control or suppression of Pseudomonas syringae pv. actinidiae. Bio-Protection Research Centre - Report No 1, 2011.

[89] Kiwifruit Vine Health. Innovation Field Trials, 2012.

[90] Frampton RA, Taylor C, Holgun Moreno AV, Visnovsky SB, Petty NK, Pitman AR, Fineran PC. Identification of bacteriophages for the biocontrol of the kiwifruit canker phytopathogen Pseudomonas syringae pv. Actinidiae. Appl Environ Microb. 2014; Ahead of print.

[91] Huang S, Ding J, Deng D, Tang W, Sun H, Liu D, et al. Draft genome of the kiwifruit Actinidia chinensis. Nat Commun. 2013;4:2640.

[92] Wei LJ, Kai-yu Y, Hong-juan G, Qiao S, Ping-ping L. Studies on morphological, physiological, and biochemical characteristic of kiwifruit canker resistant germplasm-resource Proceedings of 1st International Symposium on Bacterial Canker of Kiwifruit (Psa). Mt Maunganui, New Zealand, 2013.

[93] Qiang F. Self-fruiting Kiwiberry (Actinidia arguta) breeding in New Zealand. Proceedings of 1st International Symposium on Bacterial Canker of Kiwifruit (Psa). Mt Maunganui, New Zealand, 2013.

[94] Datson P, Manako K, Herrick J, Martinez-Sanchez M, Curtis C, Montefiori M. Monitoring the Actinidia germplasm for resistance to Pseudomonas syringae pv. actinidiae. Proceedings of 1st International Symposium on Bacterial Canker of Kiwifruit (Psa). Mt Maunganui, New Zealand, 2013.

[95] Cipriani G, Bevilacqua D, Terlizzi M, Di Cinto A, Rosato T, Sartori A, Ferrante P, Alberti F, Scortichini M. Selection of genotypes resistant or tolerant to Pseudomonas syringae pv. actinidiae (Psa) through EMS mutagenesis. Proceedings of 1st International Symposium on Bacterial Canker of Kiwifruit (Psa). Mt Maunganui, New Zealand, 2013.

[96] Granger A. Plant \& Food Research: New Zealand breeding programme. Acta Hort. 2011;913:59.

[97] Ferguson, A. 2010. Kiwifruit: Evolution of a crop. Acta Hort. 913:31-42.

[98] Datson P, Ferguson A. Actinidia. In: Kole C (editor). Wild Crop Relatives: Genomic and Breeding Resources. Berlin Heidelberg: Springer; 2011. p. 1.

[99] Ferrante P, Scortichini M. Identification of Pseudomonas syringae pv. actinidiae as causal agent of bacterial canker of yellow kiwifruit (Actinidia chinensis Planchon) in central Italy. J Phytopathol. 2009;157:768.

[100] Koh JK, Nou IS. DNA markers for the identification of P. syringae pv. actinidiae. Mol Cells. 2002;13:309.

[101] Rees-George J, Vanneste J, Cornish DA et al. Detection of Pseudomonas syringae pv. actinidiae using polymerase chain reaction (PCR) primers based on the 16S-23S rDNA intertranscribed spacer region and comparison with PCR primers based on other gene regions. Plant Pathol. 2010;59:453.

[102] Gallelli A, L'Aurora A, Loreti S. Gene sequence analysis for the molecular detection of Pseudomonas syringae pv. actinidiae: Developing diagnostic protocols. J Plant Pathol. 2011;93:425.

[103] Biondi E, Galeone A, Kuzmanovic N, Ardizzi S, Lucchese C, Bertaccini A. Pseudomonas syringae pv. actinidiae detection in kiwifruit plant tissue and bleeding sap. Ann Appl Biol. 2013;162:60.

[104] Gallelli A, Talocci S, Pilotti M, Loreti S. Real-time and qualitative PCR for detecting Pseudomonas syringae pv. actinidiae isolates causing recent outbreaks of kiwifruit bacterial canker. Plant Pathol. 2013;63:264. 
[105] Costa G, Donati I, Mauri S, Graziani S, Cellini A, Buriani G, Fiorentini L, Rocchi L, Giacomuzzi V, Spinelli F. Influence of orchard management on kiwifruit bacterial disease. Proceedings of 1st International Symposium on Bacterial Canker of Kiwifruit (Psa). Mt Maunganui, New Zealand, 2013.

[106] Spinelli F, Cellini A, Biondi E, Blasioli S, Buriani G, Donati I, et al. Preliminary results on the use of electronic nose for the early diagnosis of bacterial canker of kiwifruit. Proceedings of 1st International Symposium on Bacterial Canker of Kiwifruit (Psa). Mt Maunganui, New Zealand, 2013. 